REGULAR ARTICLE

\title{
COMPARATIVE ADVANTAGES AND SPECIALISATION OF THE VISEGRAD COUNTRIES AGRI-FOOD TRADE
}

\author{
Attila Jambor
}

\author{
Address: Attila Jambor, \\ Corvinus University of Budapest, Department of Agricultural Economics and Rural \\ Development, Fovam ter 8, 1093-Budapest, Hungary
}

Corresponding author: attila.jambor@uni-corvinus.hu

\begin{abstract}
The Visegrad Countries (V4) accession to the European Union in 2004 caused several changes in the field of agriculture. The aim of this paper is to analyse impact of the EU enlargement on V4 agri-food trade, especially considering revealed comparative advantages. Results suggest that intensity of the V4 agri-food trade has increased significantly after the enlargement. There was deterioration in the V4 agri-food trade balance with the EU15 in most cases. All analysed countries experienced a decrease in their comparative advantage, though it still remained on acceptable level in most cases. We observed weakening comparative advantage stability, underpinned by convergence of revealed comparative advantage pattern. By estimating the survival function, we found that the enlargement changed survival time of the V4 agri-food trade. Revealed comparative advantage is shown not to be persistent.
\end{abstract}

Keywords: EU enlargement, agri-food trade, Visegrad Countries

JEL classifications: Q17 


\section{INTRODUCTION}

The Visegrad Countries (the Czech Republic, Hungary, Poland and Slovakia, V4) accession to the European Union in 2004, along with six other countries, caused several changes in the field of agriculture. Transformation of national agri-food trade was one of the major changes indicated by several authors (Fertő, 2008; Baráth et al., 2010; Svatos and Smutka, 2011; Jambor, 2010).

Fertö (2008), for instance, analysed evolving pattern of the Central European countries agri-food trade using recently developed empirical procedures based on the Balassa index. His results suggest that agri-food trade pattern has converged in the Czech Republic, Hungary, Lithuania, Poland and Slovenia, while it polarised in Estonia, Latvia and Slovakia over the period. Indices were found to be stable for product groups with comparative disadvantage, but product groups with weak to strong comparative advantage showed significant variation.

Kiss (2011) found that competition in the Central and Eastern European domestic markets increased significantly after accession as a result of massive import penetration. Kiss (2007) analysed changes in agri-food trade of Hungary since the EU accession and concluded that national agri-food trade balance decreased in trade with EU27. Rusali (2010) investigated post-accession trends in agri-food trade of Romania and showed that the low competitiveness of the processing sector was the main disadvantage in achieving higher export revenue.

Bojnec and Ferto (2008a) analysed the EU New Member States (NMS) agri-food trade competitiveness. According to them, trade has increased as a result of the enlargement, though there had been 'catching-up' difficulties for some countries in terms of price and quality competition, more so in higher value-added processed products. Bojnec and Ferto (2008b) analysed price and quality competition in the Hungarian and the Slovenian bilateral agri-food trade and confirmed, that separation of one-way non-price competition from price and quality competition in two-way trade is important for small countries.

Bojnec and Ferto (2012) investigated complementarities of trade advantage and trade competitiveness measures for agro-food trade of five Central European Countries with the European Union. Revealed trade advantage was consistent with one way export and the successful price and quality competition categories with two way trade.

Torok and Jambor (2012) found that almost all NMS experienced a decrease in their comparative advantage after accession. They found weakening trend of comparative advantage stability, underpinned by convergence of revealed comparative advantage pattern. Jambor and Hubbard (2012) reached similar conclusions analysing the Hungarian agri-food 
trade after the EU accession. Accession radically changed the survival time of agri-food trade. Revealed comparative advantage was not persistent.

Baráth et al. (2010) analysed agricultural export growth rates, multifactor productivity and their correlation in the V4 countries. Average annual growth rate of multifactor productivity was the highest in Poland, while the lowest in the Czech Republic. Results also suggest that different annual average growth rates of multifactor productivity of agriculture influence agricultural export performance of the V4 countries.

Svatos and Smutka (2011) analysed development of the V4 agricultural trade. They found significant trade growth from 1993 to 2008, while commodity structure of exports was constantly narrowed. Their sensitivity analysis suggests that primary agricultural products exhibit less sensitivity in comparison with processed products.

The aim of the paper is to analyse of the EU enlargement impact on the V4 agri-food trade. The paper is structured as follows. First, methods and data used are given, followed by an analysis of structural changes in the V4 agri-food trade, providing a background for analysis. The second part of the paper analyses specialisation and stability of the V4 agri-food trade with the EU15. The last part concludes.

\section{MATERIAL AND METHODS}

The various methods of revealed comparative advantages quantification provide the basis for analysis. The index of revealed comparative advantage (B index) was first published by Balassa (1965):

$$
\mathrm{B}_{\mathrm{ij}}=\left(\frac{X_{i j}}{X_{i t}}\right) /\left(\frac{X_{n j}}{X_{n t}}\right),
$$

Where: $x$ means export, $i$ indicates a given country, $j$ is for a given product, $t$ stands for a group of products and $n$ for a group of countries.

It follows that revealed comparative advantage or disadvantage index of exports to reference countries can be calculated by comparing a given country's export share from its total export - in correlation with the focus country's export share in their total export. If B $>1$, a given country has a comparative advantage compared to focus countries - or, in contrast, a revealed comparative disadvantage. 
The Balassa-index is especially criticized because it is seen to neglect different effects of agricultural policies and asymmetric values. Trade structure is distorted by different state interventions and trade limitations, while the asymmetric value of the $\mathrm{B}$ index reveals that it extends from one to infinity if a country enjoys comparative advantage from a product, but in case of comparative disadvantage, it varies between zero and one, which overestimates a sector's relative weight. Vollrath (1991) suggested three different specifications of revealed comparative advantages in order to eliminate the disadvantages of the Balassa-index.

Due to these critiques, we use the Revealed Symmetric Comparative Advantage (RSCA) index, developed by Dalum et al. (1998), thereby tackling the problems of the B index cited above. The RSCA index is a transformed B index as follows:

$$
\mathrm{RSCA}=(\mathrm{B}-1) /(\mathrm{B}+1)
$$

The RSCA takes values between -1 and 1 , with values between 0 and 1 indicating a comparative export advantage and values between -1 and 0 a comparative export disadvantage. Since the RSCA distribution is symmetric around zero, a potential bias in the regression coefficients is avoided (Dalum et al., 1998).

In order to calculate the indices mentioned above, we used the Eurostat trade database by the HS6 system. Agri-food trade is defined as trade in food and beverages (HS 1-24), resulting in 848 products in 24 products groups pertaining to agriculture. Yearly trade data from 1999 to 2010 and data for two sub-periods (1999-2004, 2005-2010) were used for analysis effects of the EU enlargement. The EU is defined as the old member states (EU15). Furthermore, in the article we concentrate on the B index (and its transformation, the RSCA index) as it excludes imports, which are more likely to be influenced by policy interventions. The possible phasing out of export subsidies is a further reason to choose a B-based index.

\section{RESULTS AND DISCUSSION}

\section{Changes in V4 agri-food trade}

Significant changes have appeared in the V4 agri-food trade with the EU15 after the EU enlargement (figure 1). Two countries (Hungary and Poland) had a positive agri-food trade balance in the period analysed. Poland was able to increase it after the EU enlargement. The Czech Republic and Slovakia had a negative agri-food trade balance with increasing deficit. The Czech Republic almost tripled her agri-food trade deficit from 1999-2004 to 2005-2010. 


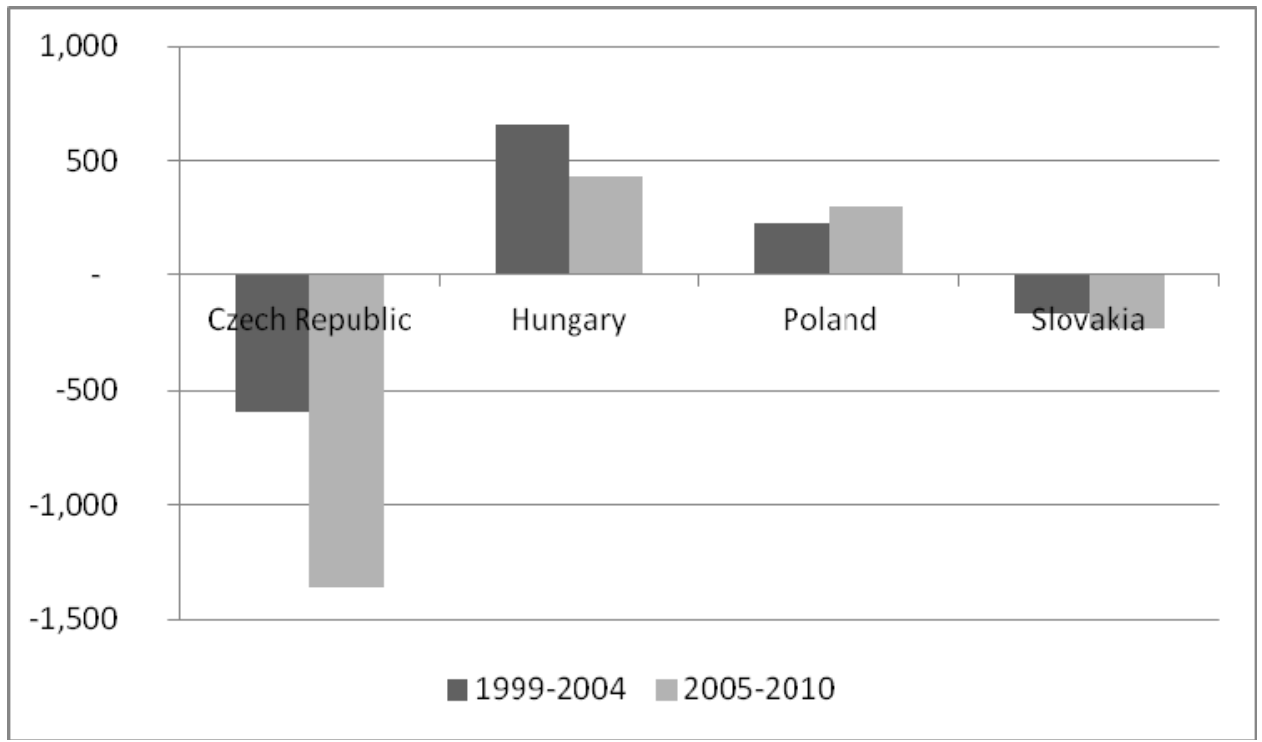

Figure 1 Agri-food trade balance of the V4 with the EU15 (mill. EUR)

Source: Own composition based on Eurostat (2012) data

Changes in structure of the V4 agri-food export by destination (table 1) are following. The EU15 share in total V4 agri-food export has increased in most countries, except Hungary. Consequently, the common market helped these countries to sell more products to the EU15. Each V4 country has increased agri-food export to the NMS. Slovakia remained the only country whose main agri-food export market was the NMS region. The rest of the world destination still play an important role in agri-food export of Hungary and Poland, but not of the Czech Republic and Slovakia (table 1). The V4 share of agri-food export to the third countries was continuously decreasing after the enlargement, while intensity of agri-food trade inside the EU increased.

Table 1 The V4 agri-food export by destination, 1999-2010 (\%)

\begin{tabular}{lrrrrrr}
\hline \hline & \multicolumn{2}{c}{ EU15 } & \multicolumn{2}{c}{ NMS } & \multicolumn{2}{c}{ Rest of the World } \\
\cline { 2 - 7 } & $1999-2004$ & $2005-2010$ & $1999-2004$ & $2005-2010$ & $1999-2004$ & $2005-2010$ \\
\hline \hline Czech Republic & 39 & 45 & 43 & 45 & 17 & 9 \\
Hungary & 50 & 50 & 21 & 31 & 29 & 19 \\
Poland & 51 & 59 & 17 & 21 & 32 & 20 \\
Slovakia & 24 & 27 & 64 & 68 & 11 & 5 \\
\hline \hline
\end{tabular}

Source: Own composition based on Eurostat (2012)

Regarding agri-food import by destination, apparently the EU15 share in total agri-food import has increased considerably after the enlargement in all countries, except Slovakia (table 2). Poland had the highest share of agri-food import from the EU15 (69\%) after the 
enlargement, while Slovakia had the lowest (32\%). The NMS as a whole absorbed small share of the NMS agri-food import, except for Slovakia, where total agri-food import from the NMS represented a considerable share $(>64 \%)$. Trade among the NMS has increased everywhere, while the importance of the third countries has declined in all cases.

Table 2 The V4 agri-food import by destination, 1999-2010 (\%)

\begin{tabular}{lrrrrrr}
\hline \hline & \multicolumn{2}{c}{ EU15 } & \multicolumn{2}{c}{ NMS } & \multicolumn{2}{c}{ Rest of the World } \\
\cline { 2 - 7 } & $1999-2004$ & $2005-2010$ & $1999-2004$ & $2005-2010$ & $1999-2004$ & $2005-2010$ \\
\hline \hline Czech Republic & 53 & 64 & 23 & 29 & 23 & 8 \\
Hungary & 51 & 61 & 18 & 30 & 32 & 9 \\
Poland & 54 & 69 & 10 & 11 & 36 & 20 \\
Slovakia & 36 & 32 & 48 & 64 & 16 & 4 \\
\hline \hline
\end{tabular}

Source: Own composition based on Eurostat (2012)

The EU enlargement enhanced intensity of the V4 and the EU15 trade relations. The EU15 share in the V4 agri-food trade has increased in most cases. The EU enlargement however, has resulted in a fall of agri-food trade balance in the V4.

\section{Specialisation of the V4 agri-food trade}

Diversity of the V4 trade specialisation was expressed by the B indices (figure 2). All countries experienced a decrease in their B index after the enlargement. This implies deterioration of their comparative advantage. All countries however, had a revealed comparative advantage $(B>1)$ in 1999-2010. Slovakia had the highest B index (17.67) before, while Poland had the lowest B index (4.44) after the enlargement. Standard deviations of the B indices over the whole sample are relatively high, suggesting significant variation from year to year with a decreasing trend after the enlargement for all analysed countries.

Similar conclusions can be drawn from analysis of the B index distribution over time. Table 3 presents basic statistics (mean, standard deviation, maximum) and distribution over time of the B index. Steadily decreasing mean of the B index means, that the V4 revealed comparative advantage has weakened after the enlargement. There was a relatively high but decreasing standard deviation and decreasing maximum values of the $\mathrm{B}$ index. The share of the $\mathrm{B}<1$ values indicate revealed comparative disadvantage of the vast majority of products on the observed period. 


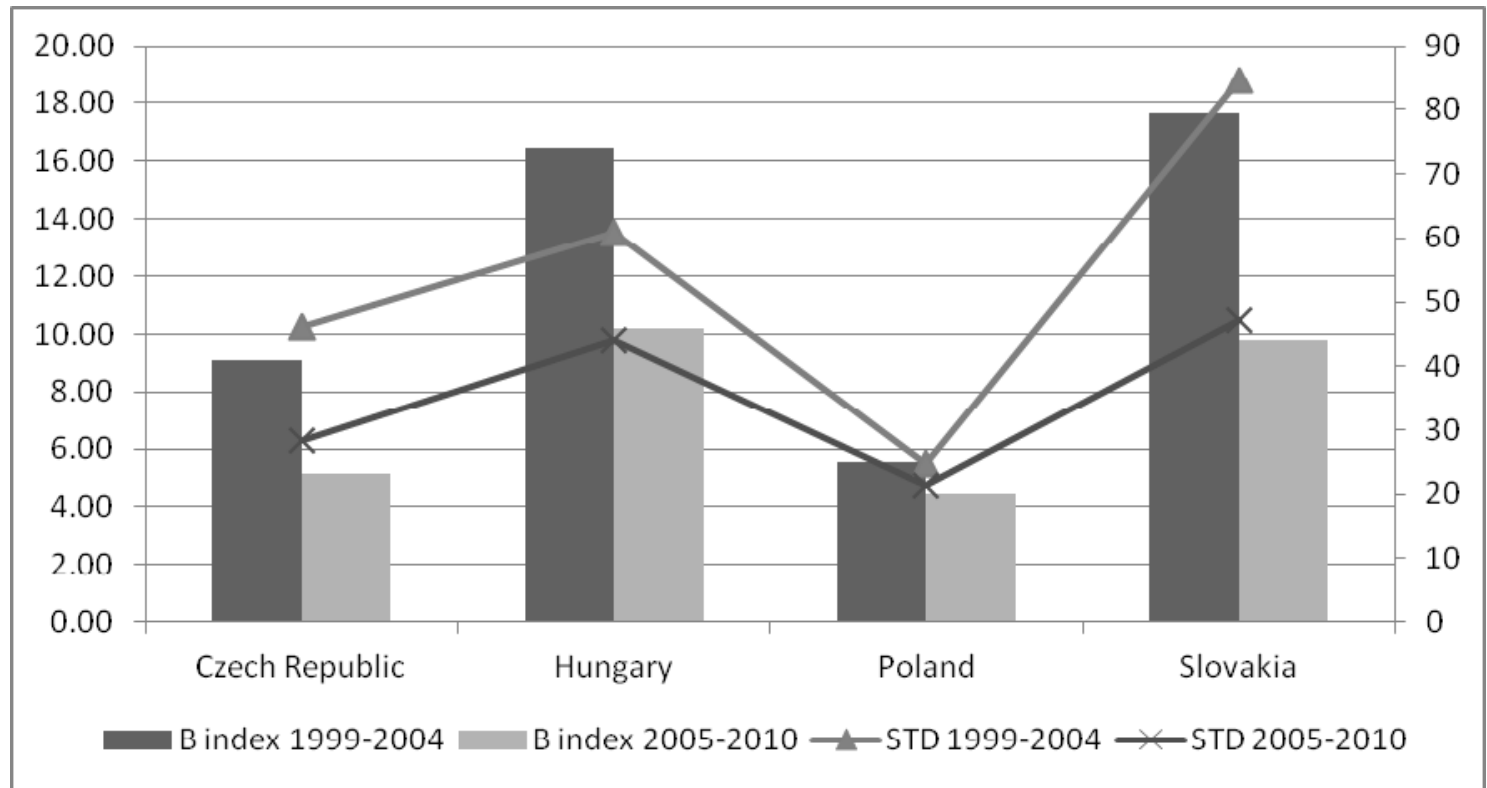

Figure 2 Revealed comparative advantage of the V4 agri-food trade in the EU15 by B index and its standard deviation, 1999-2010

Source: Own composition based on Eurostat (2012). Data for Poland and Slovakia are available from 2004; STD stands for standard deviation;

Table 3 Distribution of B index in the V4, 1999-2010

\begin{tabular}{lrrrrrrrrrrrr}
\hline \hline Year & 1999 & 2000 & 2001 & 2002 & 2003 & 2004 & 2005 & 2006 & 2007 & 2008 & 2009 & 2010 \\
\hline \hline Mean & 15.2 & 13.6 & 13.1 & 11.5 & 10.8 & 9.5 & 10.4 & 7.4 & 5.8 & 5.7 & 6.0 & 4.6 \\
Standard & 68.7 & 65.7 & 58.3 & 46.3 & 40.7 & 47.2 & 58.8 & 33.4 & 28.4 & 31.2 & 34.7 & 21.8 \\
$\begin{array}{l}\text { Deviation } \\
\text { Maximum }\end{array}$ & 862 & 958 & 711 & 592 & 511 & 970 & 896 & 541 & 627 & 746 & 822 & 447 \\
$\begin{array}{l}\text { Per cent } \\
<1\end{array}$ & & & & & & & & & & & & \\
$<2$ & 0.67 & 0.67 & 0.67 & 0.65 & 0.63 & 0.68 & 0.68 & 0.68 & 0.68 & 0.70 & 0.71 & 0.71 \\
$<4$ & 0.06 & 0.06 & 0.06 & 0.07 & 0.08 & 0.07 & 0.07 & 0.07 & 0.09 & 0.08 & 0.08 & 0.09 \\
$>4$ & 0.06 & 0.06 & 0.06 & 0.07 & 0.08 & 0.07 & 0.07 & 0.07 & 0.07 & 0.07 & 0.06 & 0.07 \\
\hline \hline
\end{tabular}

Source: Own composition based on Eurostat (2012)

\section{Stability of revealed comparative advantage}

Results above show specialisation of the V4 agri-food trade with the EU15, though fails to demonstrate stability of revealed comparative advantage. The question how persistent is the V4 agri-food trade structure can be analysed in many ways, though econometric logic suggests to use the RSCA indices instead of B indices, as the RSCA distribution is symmetric around zero. 
Stability of the RSCA index was analysed by a Galtonian regression model which compare the distribution of the RSCA for each country (sector $i$ in country $j$ ) at two points $(\mathrm{t} 1, \mathrm{t} 2)$ in time (Eq. 3):

$$
\operatorname{RSCA}_{\mathrm{ij}}^{\mathrm{t} 2}=\alpha_{\mathrm{i}}+\beta_{\mathrm{i}} \mathrm{RSCA}_{\mathrm{ij}}^{\mathrm{t} 1}+\varepsilon_{\mathrm{ij}}
$$

where $\alpha$ and $\beta$ are standard linear regression parameters and $\varepsilon$ is a residual term.

If $\beta=1$, then this suggests an unchanged pattern of the RSCA between periods $t 1$ and $t 2$. This means no change in the overall V4 agri-food trade specialization. If $\beta>1$, then the V4 agrifood trade specialization is strengthened. A low level of specialization in the initial period leads to less specialization in the future ( $\beta$ divergence). If $0<\beta<1$, commodity groups with low initial $\mathrm{B}$ indices experience growth over time ( $\beta$ convergence). However, if $\beta<0$, a change in index sign is shown.

According to Dalum et al. (1998) $\beta>1$ is not a necessary condition for growth in the overall specialization pattern. They argue that sufficient conditions for specialization or despecialization need further analyses. If $\mathrm{R}$ is a correlation coefficient, then the pattern of a given distribution is unchanged when $\beta=R$. If $\beta>R$, then the degree of specialization has grown (leading to divergence). If $\beta<\mathrm{R}$, then the degree of specialization has fallen (meaning convergence).

By using our dataset to estimate various lags for the Equation 3, the resulting $\beta$ values show that trade patterns have significantly changed after the enlargement (table 4). By running the model with a single lag, the value of $\beta$ was relatively high. With increasing the number of time lags, the $\beta$ values measurably decreases. The $\beta$ values indicate that the pattern of revealed comparative advantage has converged. The low B values increased over time, while high B values decreased and indicate the V4 agri-food trade de-specialisation after the EU enlargement. These results are also underpinned by the $\beta / \mathrm{R}$ values, as suggested by Dalum et al. (1998). The hypothesis of B index divergence can be rejected.

The comparative advantage duration before and after the EU enlargement were assessed by the survival function $\mathrm{S}(\mathrm{t})$, estimated by the non-parametric Kaplan-Meier product limit estimator, which pertains to the product level distribution analysis of the RSCA index. Following Bojnec and Fertő (2008) it is assumed, that a sample contains $n$ independent observations denoted $(t i ; c i)$, where $i=1,2, \ldots, n$ and $t i$ is the survival time, while $c i$ is the censoring indicator variable $\mathrm{C}$ (taking on a value of 1 if failure occurred, and 0 otherwise) of observation i. Moreover, it is assumed that there are $m<n$ recorded times of failure. Then, we 
denote the rank-ordered survival times as $t(1)<t(2)<\ldots<t(m)$. Let $n j$ indicate the number of subjects at risk of failing at $t(j)$ and let $d j$ denote the number of observed failures. The Kaplan-Meier estimator of the survival function is then (with the convention that $\hat{S}(t)=1$ if $t<t(1))$

$$
\hat{S}(t)=\prod_{t(i)<t} \frac{n_{j}-d_{j}}{n_{j}}
$$

Table 4 Stability of the RSCA index between 1999 and 2010

\begin{tabular}{crrrrrrr}
\hline \hline Lags & $\alpha$ & $\beta$ & $\mathrm{p}$-value & $\mathrm{R}^{2}$ & $\mathrm{R}$ & $\beta / \mathrm{R}$ & $\mathrm{N}$ \\
\hline \hline 1 & -0.0284 & 0.8928 & 0.0000 & 0.8107 & 0.9004 & 0.9916 & 12129 \\
2 & -0.0488 & 0.8335 & 0.0000 & 0.7159 & 0.8461 & 0.9851 & 10549 \\
3 & -0.0607 & 0.7833 & 0.0000 & 0.6434 & 0.8021 & 0.9765 & 8838 \\
4 & -0.0699 & 0.7435 & 0.0000 & 0.5903 & 0.7683 & 0.9677 & 7293 \\
5 & -0.0875 & 0.7047 & 0.0000 & 0.5366 & 0.7325 & 0.9620 & 5835 \\
6 & -0.1010 & 0.6682 & 0.0000 & 0.4863 & 0.6974 & 0.9582 & 4459 \\
7 & -0.1150 & 0.6380 & 0.0000 & 0.4489 & 0.6700 & 0.9522 & 2998 \\
8 & -0.1299 & 0.6097 & 0.0000 & 0.4113 & 0.6413 & 0.9507 & 2406 \\
9 & -0.1522 & 0.5834 & 0.0000 & 0.3779 & 0.6147 & 0.9490 & 1807 \\
10 & -0.1551 & 0.5688 & 0.0000 & 0.3603 & 0.6002 & 0.9476 & 1228 \\
11 & -0.1542 & 0.5688 & 0.0000 & 0.3606 & 0.6005 & 0.9472 & 633 \\
\hline \hline
\end{tabular}

Source: Own calculations based on Eurostat (2012)

By estimating the survival function to the sample, it is observable that the enlargement has radically changed the survival time of agri-food trade, meaning that revealed comparative advantage has not turned out to be persistent in the period analysed (table 5). Irrespective of the specific country, it is apparent that $94-96 \%$ survival chances fell back to $4-10 \%$ from 1999 to 2010 correspondingly. The enlargement has created a fierce competition in agri-food trade where only the most viable could remain. The greatest decline of agri-food trade survival changes can be seen in the Czech Republic, while the smallest was in Poland.

It is worth checking the equality of the survival functions across product groups by using non-parametric Wilcoxon test and log-rank test. Results show that the hypothesis of equality of the survival function across product groups can be rejected at $1 \%$ level of significance. It means no similarities exist across product groups in the comparative advantage duration (table 5). 
Table 5 Kaplan-Meier survival rates for the RSCA index for equality of survival function in V4 agri-food trade with the EU15, 1999-2010

\begin{tabular}{lrrrrr}
\hline \hline Survival rates & Total & $\begin{array}{c}\text { Czech } \\
\text { Republic }\end{array}$ & Hungary & Poland & Slovakia \\
\hline \hline 1999 & 0.9682 & 0.9451 & 0.9508 & n.a. & n.a. \\
2000 & 0.9357 & 0.8870 & 0.9022 & n.a. & n.a. \\
2001 & 0.9041 & 0.8301 & 0.8537 & n.a. & n.a. \\
2002 & 0.8733 & 0.7796 & 0.7977 & n.a. & n.a. \\
2003 & 0.8425 & 0.7262 & 0.7434 & n.a. & n.a. \\
2004 & 0.7638 & 0.6583 & 0.6749 & 0.9027 & 0.9131 \\
2005 & 0.6874 & 0.5844 & 0.6152 & 0.8025 & 0.8477 \\
2006 & 0.5977 & 0.4969 & 0.5535 & 0.6963 & 0.7387 \\
2007 & 0.5018 & 0.4031 & 0.4755 & 0.5824 & 0.6418 \\
2008 & 0.3888 & 0.2976 & 0.3905 & 0.4543 & 0.4938 \\
2009 & 0.2585 & 0.1810 & 0.2874 & 0.2968 & 0.3385 \\
2010 & 0.0737 & 0.0401 & 0.0900 & 0.0946 & 0.0953 \\
Log-rank test & 0.0000 & 0.0000 & 0.0000 & 0.0000 & 0.0000 \\
Wilcoxon test & 0.0000 & 0.0000 & 0.0000 & 0.0000 & 0.0000 \\
\hline \hline
\end{tabular}

n.a.: Data for Poland and Slovakia are just available from 2004

Source: Own calculations based on Eurostat (2012)

\section{The policy response}

By analysing the V4 agri-food trade with the EU15 over the period 1999-2010, it becomes evident that revealed comparative advantages in agri-food exports have significantly weakened since the EU enlargement and their survival rate has also decreased.

Observed changes could originate in external and internal causes. The most important external reasons were the EU enlargement, subsequent changes in trade policy and opening of national agri-food markets to the EU competition. The V4 imports of high value-added and price-competitive processed products markedly increased, while exports continue to be the more easily substitutable bulk agri-food products. Processed products from the EU15 are much more price competitive on national markets than the V4 raw materials on the old EU member state markets.

Further external factor has been a tough V4 adjustment to the new market conditions. The EU membership has made the V4 a part of large and competitive market. Whilst this offers tremendous opportunities for their agricultural sectors, the V4 are faced with significantly increased competition on their domestic markets. This reflects a rapid emergence of vertically coordinated food chains, including hypermarkets, supermarkets and multinational agro-processing companies with regional procurement systems; and the new and much more competitive conditions for producers and consumers (Csaki and Jambor, 2010). 
Uneven support of competitors under the Common Agricultural Policy is another important external cause. Traditionally high agricultural subsidies of the EU15 have artificially increased the competitiveness of their agri-food products imported by the V4 countries and generated unequal competitive market positions. Moreover, adjustment to the EU subsidy levels, coupled with gaining acquaintance of the new system and establishment of necessary institutional infrastructure have been time consuming, which has delayed the V4 region response to address its competitive disadvantages.

Several internal factors have also contributed to unfavourable development of the V4 agri-food trade. First, the V4 agri-food export competitiveness has been decreasing for many years, caused by several inner problems in agriculture of the V4 countries (dual production structure, lack of capital, lack of land consolidation, etc.). Agricultural production structure has moved after the EU enlargement towards a more extensive one, namely towards crop production. The structure became more extensive even in those countries in which crop production already dominated before the enlargement (Csaki and Jambor, 2010).

Another internal reason behind unfavourable changes in agri-food trade balance can be associated with the regional agri-food processing industries problems like internal market loss or declining performance indicators. The V4 regional industry is still suffering from the 'double pressure' where high prices of agricultural raw materials and energy, in addition to the obligatory EU standards after the enlargement, have all made the manufacture of processed products more expensive. Additional costs however, are difficult to pass on to consumers due to the fierce price competition.

\section{CONCLUSION}

The paper analysed impact of the V4 accession to the EU on agri-food trade, especially on revealed comparative advantages. We found that the V4 agri-food trade intensity has increased significantly after the enlargement. There was a diverse effect of the enlargement on the V4 agri-food trade balance. Hungary and Poland had a positive agri-food trade balance over the observed period and only Poland was able to increase it after the EU enlargement. On the other hand, the Czech Republic and Slovakia had a negative agri-food trade balance with increasing deficit. The EU15 share in the V4 agri-food trade has increased in the majority of cases.

Diversity in the V4 agri-food trade specialisation becomes apparent. All countries experienced a decrease in their B index after the enlargement, what indicate deterioration in 
their comparative advantage. All countries however, had a revealed comparative advantage (B $>1)$ in 1999-2010. Standard deviation was relatively high, but decreasing over the period, while the B index maximum values were also decreasing. We found weakening stability of comparative advantage, underpinned by convergence of the revealed comparative advantage pattern. The EU enlargement has radically changed the survival time of the V4 agri-food trade. Revealed comparative advantage is shown not to be persistent over the observed period.

Acknowledgments: The authors gratefully acknowledge financial support from the Hungarian Scientific Research Fund No. 83119 "Changes and determinants of Central and Eastern European agricultural trade”.

\section{REFERENCES}

BALASSA, B. 1965. Trade Liberalization and „Revealed” Comparative Advantage. The Manchester School, vol. 33. 1965, 99-123.

BARÁTH, L. - NAGY, ZS. AND SZABÓ, G. 2010. The correlation between the agricultural productivity and the export performance of the agro-food foreign trade in the Visegrád Group countries following accession to the European Union. Studies in Agricultural Economics, 112, 55-68.

BOJNEC, Š. - FERTÖ, I. 2008. European Enlargement and Agro-Food Trade. In Canadian Journal of Agricultural Economics, vol. 56, 2008, no. 4, 563-579.

BOJNEC, Š. - FERTÖ, I. 2008A. European Enlargement and Agro-Food Trade. In Canadian Journal of Agricultural Economics, vol. 56, 2008, no.4, 563-579. (nie je tu chyba? Rovnaké strany ako predchádzajúci zdroj.)

BOJNEC, Š. - FERTŐ, I. 2008B. Price Competition vs. Quality Competition: The Role of One-Way Trade. In Acta Oeconomica, vol. 58, 2008, no. 1, 61-89.

BOJNEC, Š. - FERTÖ, I. 2012. Complementarities of trade advantage and trade competitiveness measures. In Applied Economics, vol. 4, 2012, no. 4, 399-408.

DALUM, B., LAURSEN, K. - VILLUMSEN, G. 1998. Structural change in OECD export specialisation patterns: De-specialisation and 'stickiness'. In International Review of Applied Economics, vol. 12, 1998, no.2, 423-443.

EUROSTAT 2012. http://epp.eurostat.ec.europa.eu/portal/page/portal/eurostat/home [Accessed September 2012] 
FERTÖ, I. 2008. The evolution of agri-food trade patterns in Central European countries. In Post-Communist Economies, vol. 20, 2008, no. 1, 1-10.

JAMBOR, A. - HUBBARD, L.J. 2012. Changes in Hungarian Agri-Food Trade Since EU Accession. Selected Poster prepared for presentation at the International Association of Agricultural Economists (IAAE) Triennial Conference, Foz do Iguaçu, Brazil, 18-24 August, 2012.

KISS, J. 2007. Hope and reality: EU accession's impact on Hungarian agri-food trade. In Studies in Agricultural Economics, 2007, no. 107. 19-28.

KISS, J. 2011. Some impacts of the EU accession on the new member states' agriculture. In Eastern Journal of European Studies, vol. 2, 2011, no. 2, 49-60.

RUSALI, M. 2010. Post-accession trends of Romania's agri-food trade. In Agricultural Economics and Rural Development, New Series, Year VII, 2010, no. 2, 267-276.

SVATOS, M AND SMUTKA, L. 2011. The analysis of individual Visegrad Group Members' Agrarian Export Sensitivity in Relation to Selected Macroeconomic Aggregations. Acta Universitatis Agriculturae and Silviculturae Mendelianae Brunensis, vol. 59, 2011, no. 4, 327-340. TOROK, A. AND JAMBOR, A. 2012. Changes in Agri-Food Trade of the New Member States since EU Accession - A Quantitative Approach. Selected Poster prepared for presentation at the International Association of Agricultural Economists (IAAE) Triennial Conference, Foz do Iguaçu, Brazil, 18-24 August, 2012.

VOLLRATH, T. L. 1991. A Theoretical Evaluation of Alternative Trade Intensity Measures of Revealed Comparative Advantage. In Weltwirtschaftiches Archiv, vol. 130, 1991, no. $2,265-279$. 